\title{
ANALISIS DIMENSIONING TRAFIK PADA JARINGAN 3G MENGGUNAKAN METODE LINIER LEAST SQUARE
}

\author{
Dikky Chandra \\ Program Sudi Teknik Telekomunikasi Jurusan Teknik Elektro \\ Politeknik Universitas Andalas, Kampus Unand Limau Manis Padang 25163 \\ Email: dikky_chandra@yahoo.com
}

\begin{abstract}
ABSTRAK
Pelanggan telekomunikasi akan bertambah dari hari ke hari. Lonjakan jumlah pelanggan ini tentu menggembirakan pelaku industri telepon seluler. Namun penambahan jumlah pelanggan juga membawa konsekuensi serius bagi operator, yaitu kapasitas jaringan untuk menjamin konektifitas pelanggannya.

Dengan menggunakan data periode dari tahun 2008 dan metode linier least square untuk melakukan prediksi trafik di tahun 2010. Perhitungan dan prediksi dilakukan untuk mendapatkan komponen nilai growth factor, high season factor, trafik akhir 2010, prediksi pelanggan akhir 2010, dan program ekspansi jaringan 3G khususnya tentang kebutuhan High Speed Downlink Packet Access (HSDPA) .

Subscriber HSDPA di Bali diperkirakan meningkat sebesar 160\% di tahun 2010, sedangkan Tren Average of Concurrent User Tahun 2010 diprediksikan akan mengalami kenaikan sekitar $206 \%$. Peningkatan jumlah pelanggan HSDPA diatasi dengan penambahan kapasitas jaringan baik disisi ekspansi maupun new collocated.
\end{abstract}

Kata kunci: Trafik, Biaya, HSDPA, Tren.

\begin{abstract}
Telecommunications customers will increase from day by day. Jump in the number of subscribers is certainly encouraging mobile phone industry. However, the number of customer additions also bring serious consequences for the operator, the network capacity to ensure connectivity customers.

The data period collected from 2008 and linear method least square is used to carry out the prediction of the traffic for 2010. The calculation and the prediction was done to get the component thought growth factor, high season factor, also end of year traffic 2010, the prediction of the end subscriber 2010, and the total expansion for 3G networks in particular High Speed Downlink Packet Access (HSDPA).

Subscriber HSDPA in Bali is expected to increase by $160 \%$ in the year 2010, while the trend of Concurrent Users Average year 2010 is predicted to increase approximately 206\%. An increasing number of HSDPA overcome by the addition of either side of the network capacity expansion and new collocated.
\end{abstract}

Keyword: Traffic, Budget, HSDPA, Trend. 


\section{PENDAHULUAN}

Semakin berkembangnya zaman dan meningkatnya mobilitas menyebabkan akan kebutuhan komunikasi yang praktis dan mudah. Salah satu solusi yang dipakai adalah digunakannya sistem telekomunikasi bergerak yang disebut juga teknologi seluler.

UMTS merupakan jawaban atas semua tuntutan dari pelanggan karena UMTS merupakan sistem komunikasi generasi ke-3, yang mampu menyediakan layanan tambahan dari sistem yang telah ada sebelumnya dalam bentuk transmisi data kecepatan tinggi dan multimedia. Selain itu juga untuk menciptakan akses tanpa batas ke layanan komunikasi bergerak pita lebar yang berlaku di seluruh dunia dengan standar yang sama. Pelanggan telekomunikasi akan bertambah dari hari ke hari. Lonjakan jumlah pelanggan ini tentu menggembirakan pelaku industri telepon seluler. Namun penambahan jumlah pelanggan juga membawa konsekuensi serius bagi operator., yaitu kapasitas jaringan untuk menjamin konektifitas pelanggannya.

Untuk menentukan kapasitas layanan dimasa mendatang, maka suatu operator akan menerapkan teori peramalan trafik yang akan terjadi di bulan bahkan pada tahun mendatang. Perkiraan trafik tidak sekedar menetapkan jumlah perancanaan dimasa mendatang namun membutuhkan kaidah yang benar, baik dari sisi statistik maupun bisnis.

\section{METODE PENELITIAN}

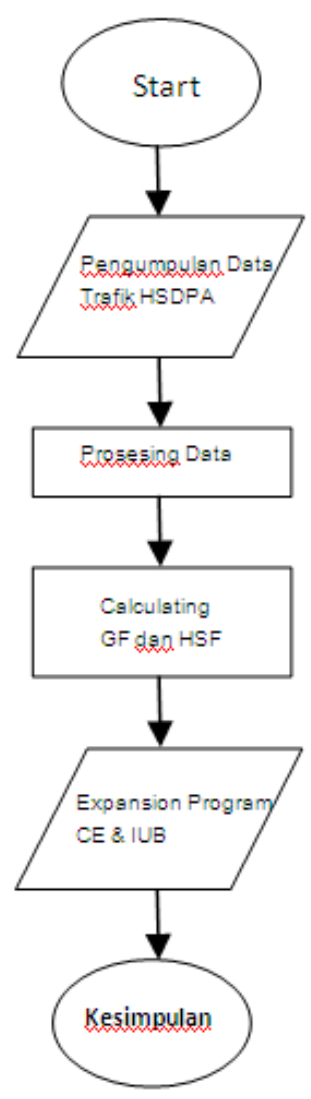

Gambar 1. Flow chart kerja dalam penentuan trafik jaringan 3G 
Analisa meliputi beberapa tahapan, yaitu pengumpulan data, pemrosesan data dan analisa data.

Tahapan yang dilakukan ialah memprediksi trafik menggunakan metode linier least square, Growth Factor, High Season Factor. Hasil dari ketiga metode tersebut akan menghasilkan jumlah trafik per-site yang akan diproses menjadi sitelist.

\section{Metode Linier Least Square}

Pendekatan Linier Least Square digunakan untuk memecahkan permasalahan dengan cara menjumlahkan kuadarat terkecil dari error yang ada berdasarkan batas terkiri dan terkanan dari data yang ada.

\section{HASIL DAN PEMBAHASAN}

Pada bagian ini akan dibahas tentang penentuan trafik prediksi per sel, utilisasi, blocking dari Channel Element dan alokasinya dalam BTS Flexsi, serta dimensioning Iub.

Utilisasi CE yang diinginkan Telkomsel untuk saat ini adalah sebesar 85\%. Jika utilisasi melebihi $85 \%$ maka akan dilakukan penambahan CE pada Node B tersebut.

\section{Alokasi CE}

Sebagai acuan yang digunakan, untuk kapasitas BTS Flexi dengan HSDPA dapat dilihat pada tabel berikut ini:

\begin{tabular}{|c|c|c|c|}
\hline HSDPA (Mbps) & HSDPA (Code) & $\begin{array}{c}\text { Offered } \\
\text { kbps }\end{array}$ & \#CE \\
\hline $1 \times 3.6$ & $1 \times 5$ & 3.360 & 240 \\
\hline $3 \times 3.6$ & $3 \times 5$ & 6.944 & 352 \\
\hline $1 \times 7.2$ & $1 \times 10$ & 5.920 & 336 \\
\hline $3 \times 7.2$ & $3 \times 10$ & 13.488 & 624 \\
\hline $3 \times 14.4$ & $3 \times 15$ & 19.632 & 624 \\
\hline
\end{tabular}

\section{IuB Dimensioning}

Jika dilihat dari class HSDPA yang digunakan, maka kebutuhan E1 untuk masing-masih clasa-nya menggunakan acuan sebagai berikut:

Kebutuhan E1 (IuB) pada BTS Flexi berdasarkan class HSDPA dapat dilihat pada tebel berikut ini:

\begin{tabular}{|c|c|}
\hline HSDPA & E1 \\
\hline $1 \times 5$ Code & 4 \\
\hline $1 \times 10$ Code & 6 \\
\hline $3 \times 5$ Code & 8 \\
\hline $1 \times 15$ Code & 8 \\
\hline $2 \times 10$ Code & 10 \\
\hline $3 \times 10$ Code & 11 \\
\hline $3 \times 15$ Code & 15 \\
\hline
\end{tabular}

\section{JARINGAN 3G DI BALI}

Di provinsi Bali telah dibangun jaringan 3G sebanyak 116 Node B.

Satu buah modul FSMB berkapasitas 240 CE dimana 26 CE digunakan untuk CCCH. Bilamana trafik telah melebihi kapasitas $214 \mathrm{CE}$ maka bisa ditambah lagi 1 buah modul FSMB berkapasitas 240 CE. Akan tetapi tidak semua tambahan CE tersebut diaktifkan, hanya yang diperlukan saja yang lisensinya telah dibeli oleh operator. Untuk itulah maka 
dilakukan manajemen trafik untuk memperkirakan kebutuhan CE di masa yang akan datang.

\section{Prediksi Data Pelanggan Hingga Akhir Tahun 2010}

Perhitungan prediksi data pelanggan dilakukan untuk mengetahui seberapa besar pertumbuhan pelanggan hingga akhir tahun 2010. Dari data pelangan yang ada dari awal tahun 2009 dapat diprediksi data jumlah pelanggan hingga akhir tahun 2010. Prediksi menggunakan metode linier least square. Dari data yang diperoleh diketahui kenaikan jumlah pelanggan hasil prediksi dapat terlihat pada Gambar berikut.

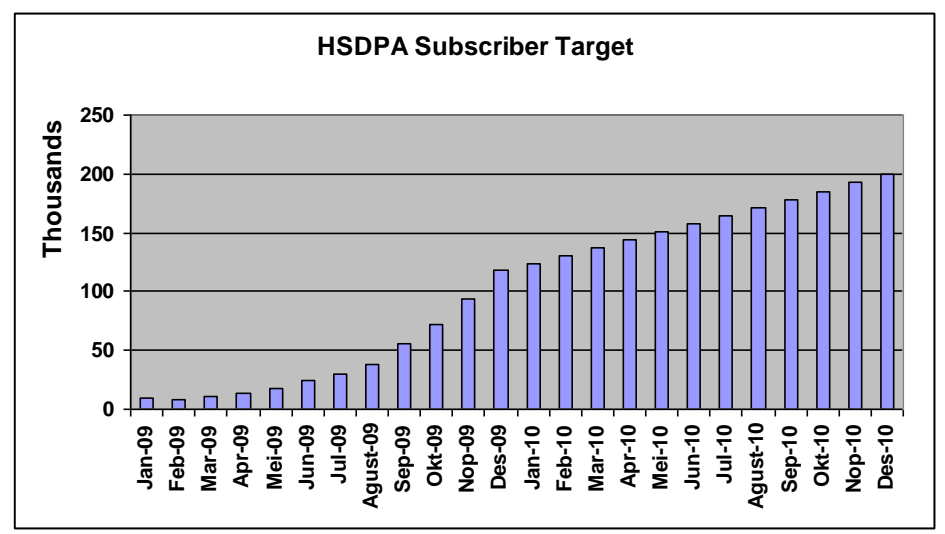

\section{Tren Average of Concurrent User Tahun 2010}

Pengumpulan data Average of Concurrent User (pengguna HSDPA yang aktif secara bersamaan), data tersebut dikumpulkan dan diurutkan berdasarkan periode minggu dari minggu pertama sampai pada minggu ke-40 (sekarang) di tahun 2009. Penggunaan data dari minggu pertama sampai dengan minggu ke-40 disebabkan karena lebih dari $80 \%$ dari 116 Node-B yang ada di Bali tersebut sudah beoperasi. Data Average of Concurrent User di area Bali dapat dilihat pada Tabel berikut ini:

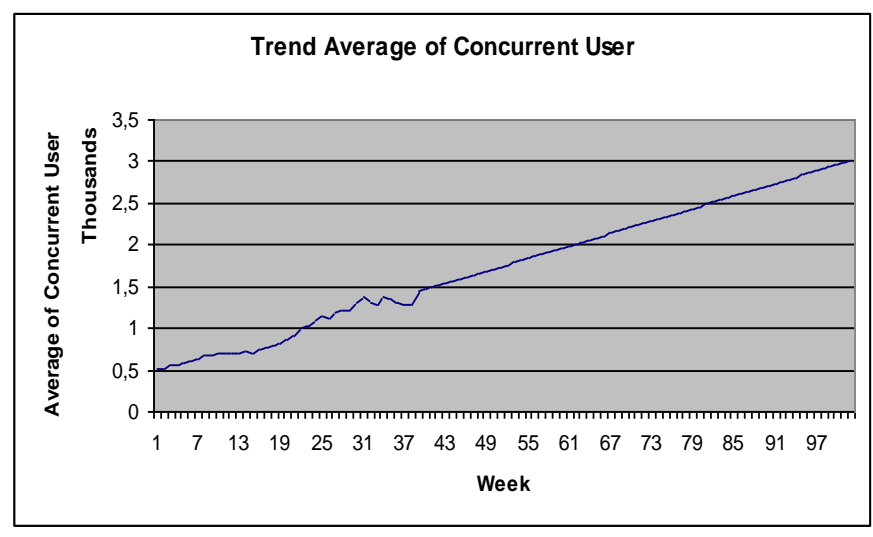

Metode prediksi berdasarkan perkembangan Average of Concurrent User di seluruh Bali. Metode tersebut akan menghasilkan 2 jenis nilai, yaitu Growth Factor dan High Season Factor. Dengan menggunakan Linier Least Square maka dapat dihitung nilai Growth Factor dan High Season Factor tersebut dan dapat di lihat pada tabel berikut ini.

Tabel GF dan HSF

\begin{tabular}{|c|c|c|}
\hline Area & GF & HSF \\
\hline Bali & 2.06 & 1.14 \\
\hline
\end{tabular}




\section{Analisa Kebutuhan Ekspansi}

Prediksi Average of Concurrent User di akhir tahun 2010 dapat diperoleh dari perkalian antara Average of Concurrent User pada minggu ke-40 (existing) dengan growth factor .

\section{Kebutuhan Class HSDPA}

\begin{tabular}{|c|c|}
\hline HSDPA Code & EoY 2010 \\
\hline $1 \times 5$ & 18 \\
\hline $1 \times 10$ & 15 \\
\hline $1 \times 15$ & 0 \\
\hline $3 \times 5$ & 5 \\
\hline $3 \times 10$ & 30 \\
\hline $3 \times 15$ & 48 \\
\hline
\end{tabular}

\section{Kebutuhan New Collocated}

Site Collocated adalah site-site $2 \mathrm{G}$ yang diusulkan untuk ditambahkan BTS 3G. Usulan ini berdasarkan atas penggunaan (Total_Packet_Volume) dari GPRS dan EDGE. Jika penggunaan (Total_Packet_Volume) pada BTS 2G tersebut melebihi 500Mbps maka site $2 \mathrm{G}$ tersebut akan ditambahkan BTS $3 \mathrm{G}$.

Dengan menggunakan data pada minggu ke40 tahun 2009 (existing), maka BTS 2G yang diusulkan untuk penambahan BTS $3 \mathrm{G}$ terdapat sebanyak 48 site.

\section{KESIMPULAN}

1. Jumlah subcriber $3 \mathrm{G}$ khususnya untuk HSDPA di Bali diprediksikan pada akhir tahun 2010 mengalami peningkatan sebesar 160\% dari tahun 2009. Sedangkan Tren Average of Concurrent User Tahun 2010 diprediksikan akan mengalami kenaikan sekitar $206 \%$.

2. Peningkatan jumlah pelanggan HSDPA harus diatasi dengan penambahan kapasitas jaringan. Dari 116 Node B di Area Bali, terdapat 98 Node B yang akan dilakukan upgrade FSMB, upgrade HSBPA class, uprgade CE dan upgrade IuB.

3. Terdapat 48 site $2 \mathrm{G}$ yang direncanakan untuk dibangun site collocated $3 \mathrm{G}$ guna menambah coverage bagi akses HSDPA. Penentuan 48 site tersebut dilihat dari penggunaan (Total_Packet_Volume) dari GPRS dan EDGE yang sudah melebihi 500 Mbit.

\section{DAFTAR PUSTAKA}

1. Siemens Training Module, 2004, PLMN ULTRAN Introduction, Siemens AG, Jerman.

2. Nokia Siemens Network Training Module, 2008, 3G Radio Planning Essentials, NPO Development.

3. Nokia Siemens Network Training Module, 2009, Review of RNC Architecture and Interfaces, Competence Development Services.

4. Nokia Siemens Network Training Module, 2008, RAN Overview and Features, NPO Development.

5. Nokia Siemens Network Training Module, 2008, RU10 UTRAN Dimensioning, NPO Development.

6. Harri Holma and Antti Toskala, 2007, WCDMA for UMTS - HSDPA Evolution and LTE. John Wiley \& Sons, Finlandia.

7. Leland Bank, P.E and Anthony Tarquin, 2002, P.E. Engineering Economy, 5th edition. Mc-Graw-Hill.. 
8. Sitorus, "Apa-itu-biaya-operasi-opex-dan-biaya-modal-capex?” Online Posting. 24 Jan 2009. http://garisgaris.wordpress.com/2009/01/24/apa-itu-biaya-operasi-opexdan-biaya-modal-capex/

9. AM Sumastutu SE, MM. Keunggulan NPV Sebagai Alat Analisis Uji Kelayakan Investasi Dan Penerapannya. 2006. <jurnal.bl.ac.id/wp-content/.../BEJ-v3-n1artikel7-agustus2006.pdf>

10. Björck, Åke., 1996, Numerical methods for least squares problems. Philadelphia, http://en.wikipedia.org/wiki/Linear_least squares

11. David White. What is ARPU? 24 October 2009. http://www.wisegeek.com/what-isarpu.htm

12. Indrawan Winata. Analisa Pendimensian Layanan UMTS yang di Implementasikan di Surabaya. 2003.

httpdigilib.petra.ac.idviewer.phppage $=1 \&$ submit. $x=0 \&$ submit. $y=0 \& q u a l=h i g h \&$ fnam e=jiunkpes1elkt2003jiunkpe-ns-s1-2003-23499091-5194-umts-abstract_toc.pdf

13. Mohammad Nur Hasan. Perencanaan Core Network di Jakarta. 2008.

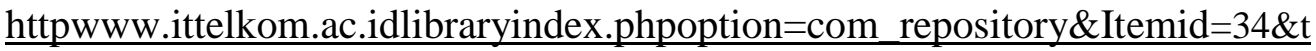
ask=detail\&nim $=111041014$

14. TIF A PUTRI REDA. Pendimensian Kapasitas Node B Pada Jaringan Wideband Code Division Multiple Access 2009

httpwww.ittelkom.ac.idlibraryindex.phpoption=com_repository\&Itemid=34\&task=de $\underline{\text { tail\&nim }=111050163}$

15. Sigit Dwi Cahyo. Analisis Prediksi Manajemen Trafik Menggunakan Metode Linier Least Square untuk Optimalisasi Anggaran. 2009. http209.85.129.132searchq=cacheI0AtxfJMPqUJwww.ee.ui.ac.idonlinemainmhs_se mtashowid5517+ANALISIS+PREDIKSI+MANAJEMEN+TRAFIK+MENGGUNA KAN+METODE+LINIER+LEAST+SQUARE+UNTUK+OPTIMALISASI+ANGG ARAN\&cd=1\&hl=id\&ct=clnk\&gl=id

16. M. Stasiak, J. Wiewióra, P. Zwierzykowski. Modeling And Dimensioning Of The IUB Interface In The UMTS Network. httpwww.ubicc.orgfilespdfUBICC_ManuScript_Piotr_v15_326.pdf 